\title{
Pembuatan Media Pembelajaran Paud Berbasis Bahan Alam Di TK Alifia Samarinda
}

\author{
Andi Aslindah ${ }^{1}$, Lilis Suryani ${ }^{2}$ \\ ${ }^{1,2}$ Universitas Widya Gama Mahakam Samarinda, Indonesia \\ andiaslindah7@gmail.com
}

\begin{abstract}
Learning media is a component that contributes to the implementation of the learning process at the education unit level. The role of the media in learning, especially in early childhood education (PAUD) is very important, considering the development of children at that time was in a period of concrete thinking.

However, there are still teachers who think that the role of the media in the learning process is only as a tool and may be ignored when the media is not available in schools. Even though the learning media used in the early childhood learning process should not be obtained from the store by buying. However, teachers and parents can create their own media.

One solution that can overcome this condition is that it is necessary to conduct a training in making creative, attractive and easily available media in a nature-based environment.

The community service activities carried out in the form of socialization and training in making learning media based on natural materials provide benefits for training participants, including: 1) For Teachers: Adding insight and increasing teacher creativity in preparing learning media by utilizing natural materials-based materials. 2) For Parents: Gained insight and experience to be more creative and innovative in assisting children to be creative in making a work (learning media) by utilizing materials that can be obtained from the natural surroundings. 3) For Children (students): Increase their self-confidence to be more skilled in performing work in creating a work (media) by collaborating with their respective parents/guardians.
\end{abstract}

Keywords: PAUD Learning Media, Natural Materials

\begin{abstract}
Abstrak
Media pembelajaran merupakan komponen yang ikut andil dalam terlaksananya proses pembelajaran dalam tingkat satuan pendidikan. Peran media dalam pembelajaran khususnya dalam pendidikan anak usia dini (PAUD) sangat penting, mengingat perkembangan anak pada saat itu berada pada masa berfikir konkrit.

Namun masih ada guru yang menganggap bahwa peran media dalam proses pembelajaran hanya sebatas sebagai alat bantu semata dan boleh diabaikan manakala media itu tidak tersedia di sekolah. Padahal media pembelajaran yang digunakan dalam proses pembelajaran anak usia dini tidak semestinya harus didapatkan dari toko dengan cara membeli. Akan tetapi guru maupun orang tua bisa menciptakan sendiri medianya.

Salah satu solusi yang bisa menanggulangi kondisi tersebut adalah perlu dilakukan suatu pelatihan pembuatan media kreatif, menarik dan mudah didapat di lingkungan sekitar yang berbasis alam.

Pada kegiatan pengabdian masyarakat yang dilakukan dalam bentuk sosialisasi dan pelatihan pembuatan media pembelajaran dengan berbasis bahan alam ini memberikan manfaat bagi peserta pelatihan, antara lain: 1) Bagi Guru : Menambah wawasan dan meningkatkan kreativitas guru dalam menyiapkan media pembelajaran dengan memanfaatkan bahan berbasis bahan alam.2) Bagi Orang Tua : Bertambah wawasan dan pengalaman untuk dapat lebih kreatif dan inovatif lagi dalam mendampingi anak untuk berkreasi membuat satu karya (media belajar) dengan memanfaatkan bahan yang bisa didapatkan dari alam sekitar. 3) Bagi Anak (siswa) : Menambah rasa percaya dirinya lebih trampil dalam berunjuk kerja menciptakan suatu karya (media) dengan berkolaborasi dengan orang tua/walinya masing-masing.
\end{abstract}

Kata Kunci: Media Pembelajaran PAUD, Bahan Alam

\section{PENDAHULUAN}

Media pembelajaran merupakan komponen yang ikut andil dalam terlaksananya proses pembelajaran dalam tingkat satuan pendidikan. Begitu pentingnya media pembelajaran terlihat dari interaksi pembelajaran yang terjadi. Semakin baik dan menarik media yang digunakan dalam proses belajar semakin mudah mencapai tujuan pembelajaran. Peranan media dalam 
URL:

http://www.sttibontang.ac.id/jurnal/index.php/pay

proses pembelajaran dapat mempertinggi proses belajar siswa dalam pembelajaran yang pada gilirannya diharapkan dapat mempertinggi hasil belajar yang dicapainya. Berbagai penelitian yang dilakukan terhadap penggunaan media dalam pembelajaran sampai pada kesimpulan, bahwa proses dan hasil belajar pada siswa menunjukkan perbedaan yang signifikan antara pembelajaran tanpa media dengan pembelajaran menggunakan media. Penggunaan media pembelajaran sangat dianjurkan untuk mempertinggi kualitas pembelajaran.

Media pembelajaran tidak hanya digunakan pada jenjang pendidikan dasar, pertama menengah dan perguruan tinggi. Akan tetapi juga dapat digunakan pada jenjang pendidikan anak usia dini. Peran media dalam pembelajaran khususnya dalam pendidikan anak usia dini (PAUD) sangat penting, mengingat perkembangan anak pada saat itu berada pada masa berpikir konkrit. Oleh karena itu salah satu prinsip pendidikan untuk anak usia dini harus berdasarkan realita artinya bahwa anak diharapkan dapat mempelajari sesuatu secara nyata. Prinsip tersebut mengisyaratkan perlunya digunakan media sebagai saluran penyampai pesan-pesan pendidikan untuk anak usia dini.

Media pembelajaran yang digunakan dalam proses pembelajaran anak usia dini tidak semestinya harus didapatkan dari toko dengan cara membeli. Akan tetapi guru maupun orang tua bisa menciptakan sendiri medianya. Bisa dengan memanfaatkan bahan-bahan bekas ataupun dari bahan alam di lingkungan sekitar yang mudah didapatkan. Namun yang perlu diingat bahwa media pembelajaran yang diciptakan oleh para guru ataupun orang tua di rumah seharusnya dapat menstimulasi berbagai aspek perkembangan pada anak usia dini, yaitu aspek perkembangan agama dan moral, kognitif, bahasa,social emosional, seni maupun kreativitas anak.

Berdasarkan uraian di atas maka penulis sebagai dosen di PG PAUD Universitas Widya Gama Mahakam Samarinda tertarik untuk melaksanakan pengabdian kepada masyarakat dalam bentuk kegiatan pelatihan pembuatan media berbasis bahan alam di TK Alifia Samarinda. Kegiatan pengabdian kepada masyarakat ini merupakan salah satu bagian dari TRI DHARMA perguruan tinggi yang merupakan kewajiban dosen selain mengajar dan penelitian.

\subsection{Permasalahan Mitra}

Beragam media seharusnya digunakan dalam menunjang proses pembelajaran. Akan tetapi kurangnya kreatifitas dan terkendalanya alat dan bahan dalam pembuatan media menjadikan penggunaan media terbatas. Masih ada guru yang menganggap bahwa peran media dalam proses pembelajaran hanya sebatas sebagai alat bantu semata dan boleh diabaikan manakala media itu tidak tersedia di sekolah. Hal ini menjadi masalah yang sering ditemui dalam lembaga-lembaga PAUD. Padahal di lingkungan sekitar banyak sekali bahan-bahan yang dapat di gunakan, misalnya dari alam guru dapat memanfaatkan alam untuk membuat media seperti daun pisang kering, biji-bijian dan batu-batuan dapat di buat menjadi kolase, tanah liat untuk pengganti play dogh/lilin,pelepah pisang atau pelepah pepaya maupun potongan sayur ibu yang tidak terpakai di dapur bisa dijadikan sebagai cetakan lukisan. Bahanbahan yang sangat mudah didapat dan sangat murah bahkan gratis.

\subsection{Solusi Permasalahan}

Berdasarkan masalah yang telah diuraikan di atas, maka dicarilah solusi, Solusi yang dimaksud adalah melakukan pelatihan pembuatan media kreatif, menarik dan mudah didapat di lingkungan sekitar yang berbasis alam. Sehingga guru dan orang tua dapat dengan mudah membuat media pembelajaran yang menarik bagi peserta didiknya yang sesuai dengan tema dan kegiatan pembelajaran yang sudah direncanakannya sehingga tujuan pembelajaran dapat tercapai. 


\subsection{Tujuan Pengabdian kepada Masyarakat}

Kegiatan pelatihan pembuatan media dari bahan alam yang diselenggarakan bertujuan untuk:

1. Meningkatkan pengetahuan guru TK Alifia dan orang tua siswa dalam hal pemanfaatan bahan alam untuk dijadikan media dan sumber pembelajaran;

2. Meningkatkan kreativitas guru dalam menyiapkan media pembelajaran sehingga dapat meminimalisir penggunaan Lembar Kerja Anak (LKA)/Majalah.

3. Memberikan variasi mengajar yang menyenangkan karena dalam menyediakan media bisa melibatkan langsung anak-anak sehingga mereka dapat belajar mencintai alam sejak dini dan diharapkan kelak menjadi individu yang lebih menghargai alam.

\subsection{Keluaran (Output)}

Beberapa manfaat yang diharapkan setelah berlangsungnya kegiatan pelatihan ini adalah:

1. Peserta pelatihan diharapkan dapat lebih kreatif dan inovatif dalam menyediakan media pembelajaran yang berbasis alam yang bisa didapatkannya dari lingkungan sekitar.

2. Peserta pelatihan termotivasi untuk lebih memanfaatkan alam sekitar untuk meningkatkan mutu pembelajaran dan menjadikan metode pembelajaran lebih bervariasi

3. Peserta pelatihan mahir membuat kolase dari macam-macam daun kering ataupun dari bahan-bahan alam yang lain.

\section{Kutipan dan Acuan}

Menurut Arsyad (dalam Kasmadi, 2013), media memiliki 4 fungsi yaitu : 1) Fungsi atensi, dalam fungsi ini media visual dapat menarik dan mengarahkan perhatian anak untuk berkonsentrasi pada pembelajaran; 2) fungsi afektif, dalam fungsi ini media visual dapat diamati tingkat kenyamanan siswa ketika pembelajaran berlangsung;3) fungsi kognitif, dalam fungsi ini media visual dapat mempercepat pencapaian tujuan pembelajaran; 4) fungsi kompensatoris, media pembelajaran dapat memberikan konteks kepada siswa yang kemampuannya lemah dalam mengorganisasikan dan mengingat kembali informasi.

Pemanfaatan media bahan alam juga sangat efektif digunakan dalam proses pembelajaran, terutama bagi anak usia dini. Media bahan alam adalah segala sesuatu yang ada di lingkungan sekitar yang sangat efektif dan efisien digunakan untuk menunjang pembelajaran. Pemanfaatan bahan alam sebagai media dapat membantu anak dalam mengembangkan berbagai aspek perkembanga baik kognitif, sosial emosional, bahasa, motorik, moral dan nilai-nilai agama serta kecakapan hidup bagi anak. Media bahan alam bisa berupa batu-batuan, kayu dan ranting, biji-bijian, daun, pelepah, bambu dan sebagainya. Kesemua bahan ini sangat mudah didapatkan dari lingkungan sekitar.

Menurut Musbikin (2010), alam dan lingkungan sekitar merupakan media yang sangat baik untuk mengajarkan banyak hal kepada manusia, terutama nbagi anak usia dini. Sebab dengan menggunakan media alam, anak akan mudah melihat dan mencerna apa yang diajarkan kepadanya.

Seperti halnya penelitian yang telah dilakukan oleh Vanni Miza Oktari tentang penggunaan media bahan alam dalam pembelajaran di Taman Kanak-kanak Kartika-63 Padang didapatkan suatu kesimpulan bahwa pemanfaatan bahan alam sebagai media pembelajaran dapat meningkatkan aspek perkembangan dan kreativitas anak. Terlihat dari anak sangat senang dan antusias mengamati dan menggunakan media yang disiapkan oleh guru. Hanya saja guru perlu lebih kreatif lagi memvariasikan media yang digunakan dalam kegiatan yang lebih bervariasi juga. Misalkan guru melibatkan anak dalam menyiapkan media bahan alam yang akan digunakan ataupun melibatkannya dalam pembuatan media. 


\section{METODE PELAKSANAAN}

Kegiatan ini dilaksanakan pada jam 08.00 - 11.00 wita, hari Rabu, 4 Desember 2019 di TK Alifia Samarinda. Struktur program kegiatan pelatihan pembuatan media yang berbasis alam sebagai berikut:

Tabel 1. Program Kegiatan

\begin{tabular}{|l|l|l|r|}
\hline No & \multicolumn{1}{|c|}{ Program } & \multicolumn{1}{|c|}{ Materi } & Alokasi Waktu \\
\hline 1. & $\begin{array}{l}\text { Presentasi dan } \\
\text { Tanya jawab }\end{array}$ & $\begin{array}{l}\text { Pentingnya media pembelajaran } \\
\text { bagi AUD }\end{array}$ & 60 menit \\
\hline 2 & Workshop & Praktek membuat media & 180 menit \\
\hline
\end{tabular}

Susunan acara kegiatan sebagai berikut:

Tabel 2. Susunan Acara

\begin{tabular}{|l|l|l|l|}
\hline No. & Waktu & Kegiatan & Pengurus \\
\hline 1. & $08.00-08.45$ & Presentasi materi & Ketua Pelaksana \\
\hline 2. & $08.45-09.00$ & $\begin{array}{l}\text { Tanya jawab seputar Materi } \\
\text { media pembelajaran PAUD }\end{array}$ & Ketua Pelaksana \\
\hline 3. & $09.00-09.10$ & Persiapan Alat dan bahan Praktek & Ketua Pelaksana/anggota \\
\hline 4. & $09.10-11.00$ & Praktek langsung & Peserta Pelatihan \\
\hline
\end{tabular}

Skenario Kegiatan

Kegiatan pelatihan yang diselenggarakan di TK Alifia Samarinda menggunakan metode praktek - pelatihan dan diskusi-konsultasi. Secara rinci metode yang dilakukan adalah sebagai berikut:

1. Penjelasan diberikan kepada peserta dalam hal Pentingnya penggunaan media dalam pelaksanaan pembelajaran anak usia dini.

2. Penjelasan tahapan pembuatan media disertai Praktek langsung membuat media pembelajaran sederhana.

3. Peserta melakukan praktek pembuatan media menggunakan bahan dari alam dengan bimbingan

4. Selama pelatihan peserta difasilitasi waktu diskusi-konsultasi untuk membahas kesulitan-kesulitan pembuatan media pembelajaran berbasis alam.

Fasilitator

Pemateri pada pelatihan ini adalah Andi Aslindah, M.Pd selaku ketua pelaksana pengabdian kepada masyarakat dan dibantu oleh mahasiswa selaku asisten dari kegiatan ini adalah Lilis Suryani 
URL:

http://www.sttibontang.ac.id/jurnal/index.php/pay

\section{HASIL DAN PEMBAHASAN}

\section{Hasil}

Kegiatan pengabdian masyarakat ini dihadiri oleh peserta yang terdiri dari Guru TK Alifia sebanyak 6 orang, mahasiswa PG PAUD 5 orang, orang tua/wali siswa sebanyak 27 orang ditambah dengan anak didik TK Alifia sebanyak 33 anak.

Berdasarkan hasil sosialisasi dan pelatihan ini diketahui bahwa sebagian guru dan banyak orangtua yang belum menyadari pentingnya penggunaan media diterapkan dalam pembelajaran di PAUD. Sosialisasi dan pelatihan ini mengambil tema tentang pembuatan media pembelajaran PAUD dengan menggunakan bahan yang berbasis bahan alam sangat diapresiasi sekali oleh para guru TK dan orang tua siswa TK Alifia. Menurut mereka wawasannya jadi terbuka untuk kreatif dalam memanfaatkan bahan-bahan alam atau bahanbahan sisa yang ada di sekitar mereka. Dalam kegiatan ini dicontohkan bahan-bahan alam yang dimaksud adalah bahan alam yang dapat dimanfaatkan sebagai media adalah jenis-jenis daun (daun segar maupun daun kering), batu-batuan, kayu dan ranting, biji-bijian, pelepah, dan lain sebagainya. Yang mungkin dalam pandangan mereka selama ini bahan alam yang dimaksud hanya berupa bahan-bahan yang tidak terpakai lagi (Sampah), tapi ternyata bisa dimanfaatkan menjadi suatu produk/karya yang menarik dan bisa dijadikan media pembelajaran bagi anak dini.

Pelaksanaan kegiatan ini berjalan sesuai dengan agenda yang sudah disusun, yang diawali dengan pembukaan oleh $\mathrm{MC}$, sambutan singkat oleh kepala sekolah kenudian dilanjutkan dengan kegiatan sosialisasi tentang pentingnya penggunaan media dalam pembelajaran di PAUD. Setelah itu, kegiatan dilanjutkan dengan kegiatan praktek langsung membuat media pembelajaran dengan teknik kolase dengan menggunakan bahan-bahan alam (macam-macam jenis daun segar dan daun kering, biji-bijian, ranting-ranting kecil) yang sudah dibawa oleh masing-masing peserta dari rumah. Sebagian bahan juga didapatkan dari halaman sekolah. Pada pelaksanaan praktek membuat media ini, anak dan orang tua/wali siswa bekerja sama mengerjakan medianya sampai selesai yang diawali oleh pembuatan pola oleh orang tua/wali siswa. Harapan dari kolaborasi antara anak dan orang tua/wali siswa ini supaya terjalin kedekatan antara anak dan orang tua, selain itu orang tua juga dapat memahami sampai dimana kemampuan anaknya dalam menyelesaikan karya/tugasnya.

Selama proses praktek berlangsung, terlihat semua peserta begitu antusias dalam mendampingi anaknya dalam membuat satu media yang menarik. Di wajah anak-anak terlihat ada rasa senang dan bangga bisa didampingi oleh orang tuanya menyelesaikan karyanya. Rasa senang dan bangga itu muncul kemungkinan disebabkan karena selama mengerjakan kegiatan di sekolah mereka hanya didampingi oleh gurunya. Sehingga mereka dengan bangga bisa menunjukkan unjuk kerjanya kepada orang tua masing-masing.

Pada kegiatan pengabdian masyarakat yang dilakukan dalam bentuk sosialisasi dan pelatihan pembuatan media pembelajaran dengan berbasis bahan alam ini memberikan manfaat bagi peserta pelatihan, antara lain:

1. Bagi Guru : Menambah wawasan dan meningkatkan kreativitas guru dalam menyiapkan media pembelajaran dengan memanfaatkan bahan berbasis bahan alam , Memberikan variasi mengajar yang menyenangkan karena dalam menyediakan media bisa melibatkan langsung anak-anak sehingga dapat meminimalisir penggunaan lembar kerja anak.

2. Bagi Orang Tua : Bertambah wawasan dan pengalaman untuk dapat lebih kreatif dan inovatif lagi dalam mendampingi anak untuk berkreasi membuat satu karya (media belajar) dengan memanfaatkan bahan yang bisa didapatkan dari alam sekitar. 
URL:

http://www.sttibontang.ac.id/jurnal/index.php/pay

3. Bagi Anak (siswa) : Menambah rasa percaya dirinya lebih trampil dalam berunjuk kerja menciptakan suatu karya (media) dengan berkolaborasi dengan orang tua/walinya masingmasing sehingga tercipta ikatan emosi positif untuk lebih semangat lagi berkreasi menciptakan media yang menarik dengan teknik kolase yang memanfaatkan bahan berbasis bahan alam (berbagai jenis daun, biji-bijian, batu-batuan dan ranting-ranting kecil). Sehingga Anak dapat belajar untuk mencintai alam sejak dini dan diharapkan kelak menjadi individu yang dapat lebih menghargai alam.

\section{Pembahasan}

Perkembangan anak pada masa usia dini berada pada masa berfikir konkrit. Oleh karena itu salah satu prinsip pendidikan untuk anak usia dini harus berdasarkan realita artinya bahwa anak diharapkan dapat mempelajari sesuatu secara nyata melalui media yang konkrit. Menurut Kustandi dan Sutjipto (2011:9) Media Pembelajaran adalah alat yang dapat membantu proses belajar mengajar dan berfungsi untuk memperjelas makna pesan yang disampaikan, sehingga dapat mencapai tujuan pembelajaran yang lebih baik dan sempurna. Oleh karena itu, peran guru dalam menentukan media dalam proses belajar mengajar, dituntut untuk kreatif dalam upaya mengembangkan berbagai jenis aspek perkembangan yang dimiliki oleh tiap anak. Salah satu cara yaitu dengan menggunakan media alam yang ada disekitar anak. Media bahan alam adalah segala sesuatu yang ada di lingkungan sekitar kita yang dapat digunakan untuk menunjang pembelajaran. Media ini sangat murah namun dapat dipergunakan secara efektif dan efesien dalam proses pembelajaran. Memanfaatkan yang ada di sekiatar alam sebagai media menjadikan anak dapat belajar dengan konkret (nyata). Melalui media bahan alam, anak akan diberikan contoh nyata dan langsung dalam kegiatan pembeajaran yang diberikan.

Bahan alam yang dapat digunakan sangat beragam, meliputi batang, ranting, daun, biibijian, batu-batuan, pasir, dan air. Banyak strategi atau teknik yang dapat digunakan dalam penggunaan bahan alam tersebut. Bisa dengan kegiatan mengelomokan berdasarkan jenis, warna, ukuran, dan bentuk. Selain itu bisa juga dengan menyusun kolase dengan menggunakan lem dan bahan-bahan pendukung lainnya (Departement Education, Training and Employment, 2012). Orang dewasa bisa membantu anak untuk mengembangkan kreativitasnya dengan memberikan kesempatan pada anak untuk mengumpulkan bahan-bahan yang bisa didapatkan dari alam sekitar.

Keuntungan dari penggunaan media bahan alam adalah tidak perlu mengeluarkan biaya mahal, bisa saja didapatkan dengan gratis. Karena bahan-bahan yang dibutuhkan tersebut sangat mudah di dapatkan dalam jumlah yang banyak. Selain itu bahan alam seperti daun dan biji yang memiliki bentuk dan tekstur yang beragam dan bervariasi sehingga kecerdasan naturalis anak dapat dikembangkan dan bisa mengajarkan anak untuk lebih mencintai dan mengahargai alam. Oleh karena itu Guru dapat memanfaatkan bahan alam sesuai dengan kegiatan pembelajaran.

Terdapat juga kelemahan dalam penggunaan bahan alam sebagai media pembelajaran antara lain adalah tidak tahan lama di simpan, seperti daun yang cepat mengering dan mengkerut sehingga tidak dapat digunakan. Selain itu biji-bijian juga tidak dapat disimpan dalam waktu yang lama karena cepat berjamur dan harus sering dibersihkan jika masih digunakan untuk jangka waktu yang lama. Guru harus pintar dalam mengolah media bahan alam yang cepat berubah baik bentuk maupun warna. 
JPAY Vol. 1 No. 1.2021

(Jurnal Pengabdian Ahmad Yani) STTI Bontang

URL:

http://www.sttibontang.ac.id/jurnal/index.php/pay

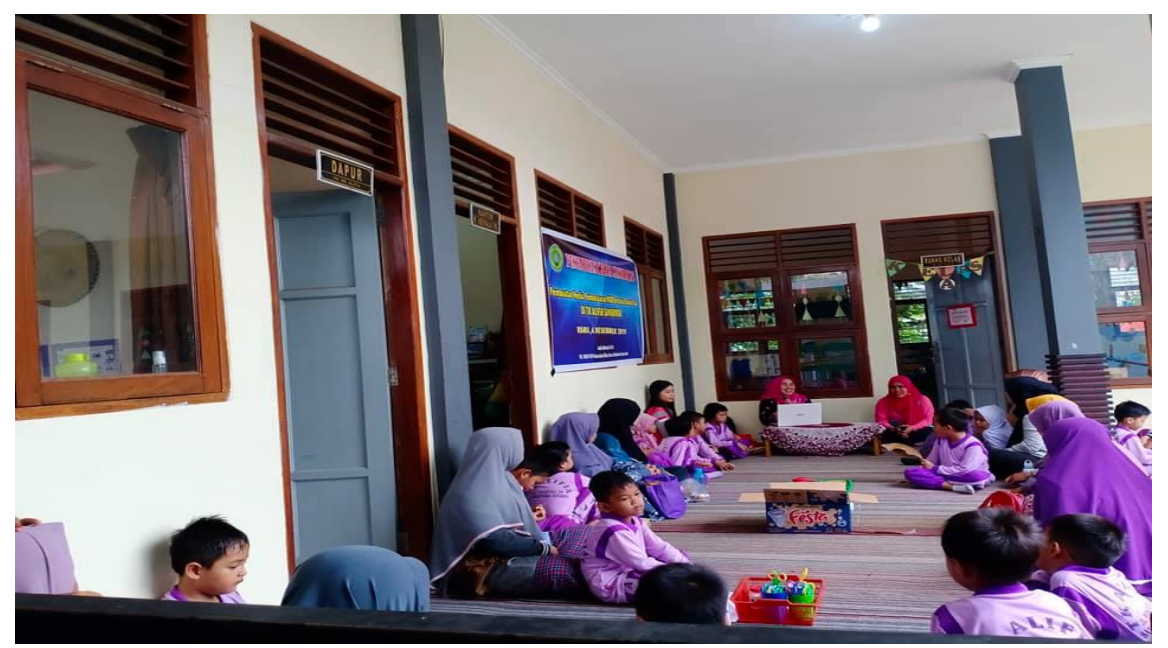

Gambar 1. Sosialisasi Pentingnya penggunaan Media diterapkan dalam pembelajaran di PAUD

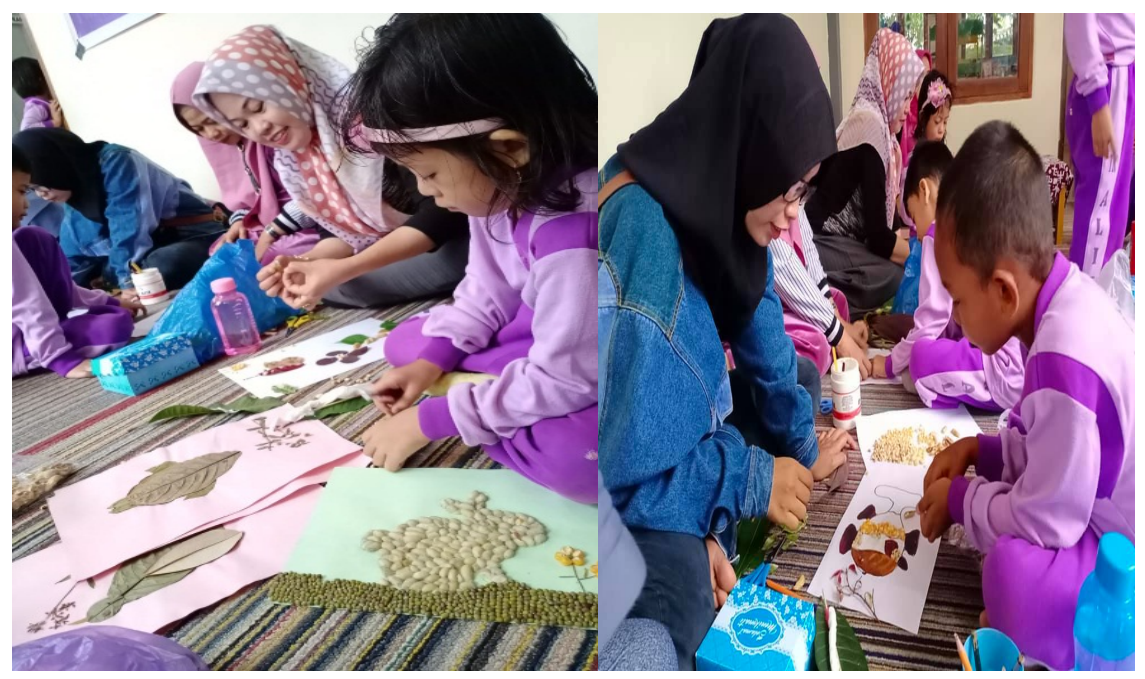

Gambar 2. Kerjasama orang tua dan anak membuat karya/media (pendampingan)

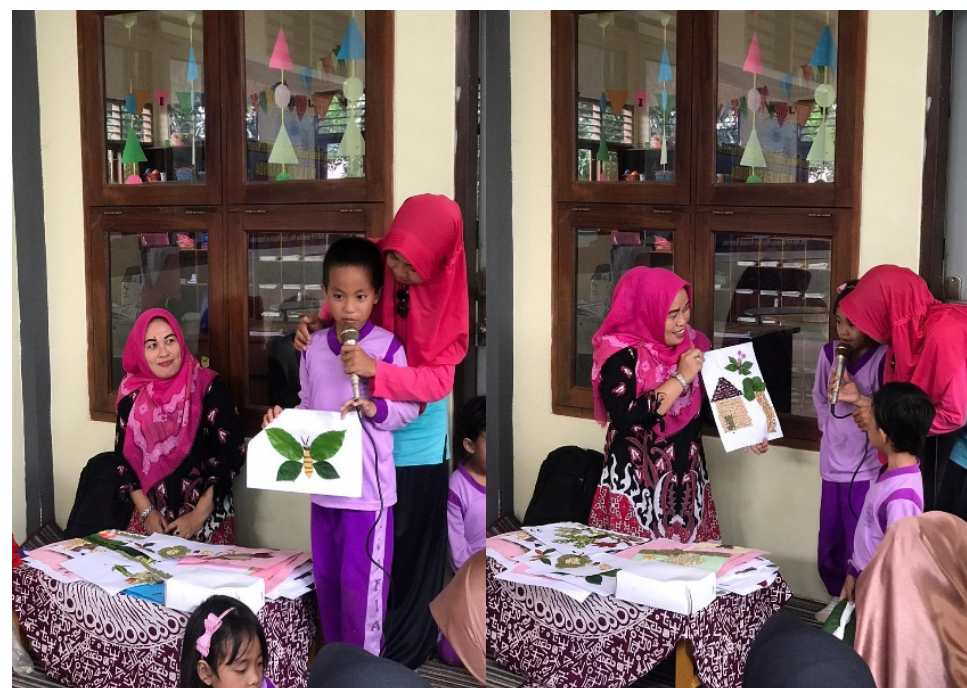


Gambar 3. Anak menceritakan hasil karyanya (konsep, proses pembuatan serta alat dan bahan yang digunakan)

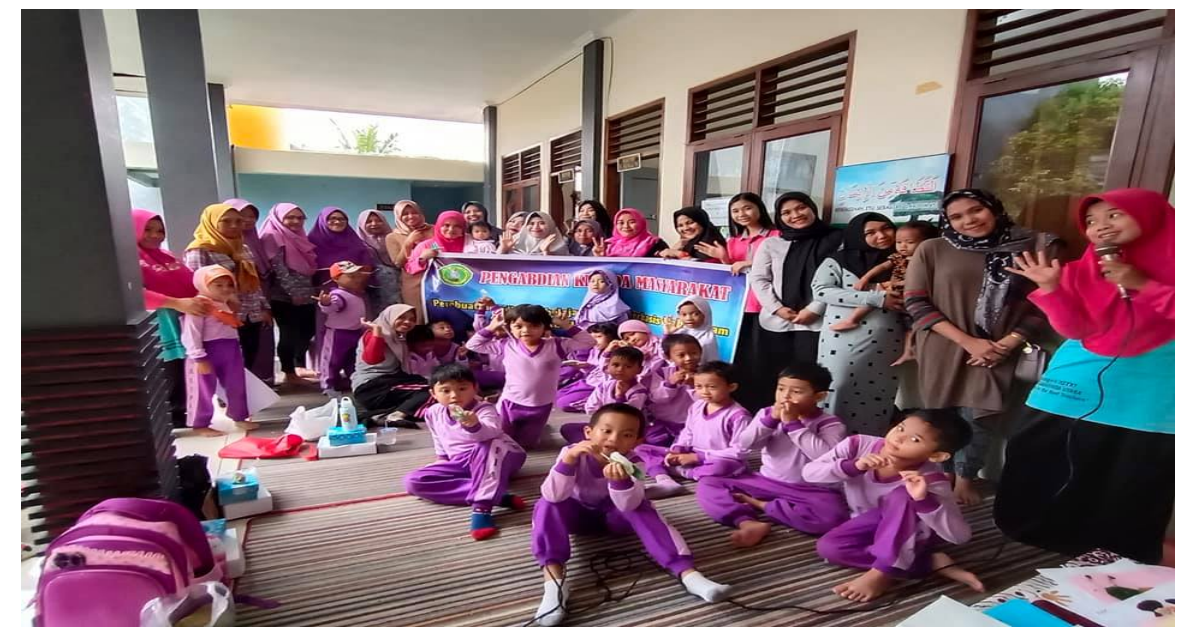

Gambar 4. Foto bersama dengan peserta Pelatihan

\section{KESIMPULAN}

\section{Kesimpulan}

Media dan sumber belajar PAUD akan membantu mendekatkan jarak pemahaman antara anak dan pendidik tentang suatu konsep dan proses yang dipelajari. Pendidik dapat menemukan dan mengembangkan media serta sumber belajar yang berbasis alam sekitar sehingga dapat mendorong dan memudahkan anak untuk menemukan sendiri tentang konsep dan proses yang dipelajari dalam kehidupan sehari-hari.

\section{Saran-Saran}

Guru diharapkan lebih kreatif dalam mengembangkan media pembelajaran dan tidak terbatas hanya pada media dan alat yang sudah ada di sekolah. Namun guru dapat memanfaatkan bahan-bahan alam dan bahan bekas yang ada di lingkungan sekitar untuk digunakan sebagai media dan alat permainan bagi anak usia dini.

Sedangkan untuk orang tua diharapkan dapat menyisihkan waktunya dan lebih kreatif lagi dalam mendampingi anak berkreasi membuat karya/media agar hubungan antara orang tua dan anak akan semakin dekat.

\section{DAFTAR PUSTAKA}

Abdussalam, A. (201 5). Mengembangkan kreativitas anak. Jakarta: Pustaka Al-Kautsar Eliyawati, Cucu. 2005. Pemilihan dan Pengembangan Sumber Belajar Untuk Anak Usia Dini.Jakarta:Depdiknas

Ibrahim, H. (2017).Media pembelajaran: Arti, fungsi, landasan pengunaan, klasifikasi, pemilihan, karakteristik oht, opaque, filmstrip, slide, film, video, Tv, dan penulisan naskah slide. Bahan sajian programpendidikan aktamengajar III-IV. FIP-IKIPMalang.

Munandar, U. (2017). Pengembangan kreativitas anak berbakat. Jakarta: Rineka Cipta. Musbikin, Imam (2010).Buku PintarPaud.Yogyakarta: Laksana. 
Musrid. (2015).Belajar dan PembelajaranPAUD.Bandung: PT RemajaRosdakarya

Rohani Ahmad, 1997. media Instruksional Edukatif. Jakarta : PT Rineka Cipta.

Sadiman, A.S.(2014).Media pendidikan: pengeratian, pengembangan, dan pemanfaatannya.Jakarta:Cv. Rajawali

Sudono,Anggani.(2014).Sumber Belajar dan Alat Permainan untuk PendidikanUsia Dini. Jakarta:Grasindo

Ulum, Irfatul. (2015). Pemanfaatan Lingkungan Sebagai Sumber Belajar Anak. Jurnal Pendidikan Anak 3 (2), hlm: 518-523.

Vanni Miza Oktari (2017) Penggunaan Media Bahan Alam dalam Pembelajaran Di Taman Kanak-Kanak Kartika I-63 Padang. PAUDLectura: Jurnal Pendidikan Anak Usia Dini, Vol1, No 1Oktober 2017

\section{Profil Penulis:}

Andi Aslindah, Kelahiran Cangadi, 01 Juni 1975. Penulis
merupakan staf pengajar di Universitas Widya Gama
Mahakam Samarinda di Fakultas FKIP Prodi Pendidikan
Anak Usia Dini.
Email : andiaslindah7@gmail.com
Lilis Suriyani Hensur La, Merupakan Mahasiswa
Universitas Widya Gama Mahakam Samarinda di Fakultas
FKIP Prodi Pendidikan Anak Usia Dini
Email : hensurla.lilissuriyani@gmail.com

